\title{
USE OF ARABIC COMMON WORDS
}

\author{
Khulkar Vasilovna Mirzakhmedova \\ $\mathrm{PhD}$, Associate Professor, \\ Tashkent State University of Oriental Studies, \\ Tashkent, Uzbekistan
}

Article DOI: https://doi.org/10.36713/epra3886

\begin{abstract}
This article reveals the use of Arabic common words. It is known that the development of terminology is inextricably linked with the product of popular thinking, that is, with the general lexicon. General lexicon is the main source of the formation of new terms. In turn, terminology also plays an important role in the enrichment of general lexicon. The more the general lexicon develops in close connection with the terminological lexicon, the more autonomously the terminology is enriched.
\end{abstract}

KEYWORDS: General lexicon, terminological lexicon, toponyms, etymological, grammatical structure.

\section{INTRODUCTION}

The emergence of language academies in Iran was supposed to preserve a pure layer of the language and replace the Arabic and Turkish words, which were already absorbed by the language, with Persian variants.

"Linguistic methods (based on topoformants, etymological, grammatical structure) are widely used by scientists in the study of geographical names. The linguistic structure of words, words and suffixes, their meanings and combinations, the socio-linguistic factors on which the name is based must be evaluated, interpreted and studied in the light of the realities of that period" [1. 26]. For this purpose, the first Academy Persianized, first of all, toponyms (toponyms), as well as words related to the active speech layer of vocabulary.

For example:

Nāseri instead اهواصرى Ahavāz.

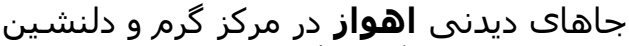

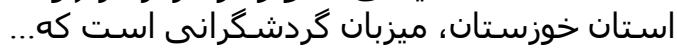

Jāhā-ye didani-ye Ahavāz dar markaz-e garm-o delnešin-e ostān-e Xuzestān, mizbān-e gardešgerānist ke...

[https://safarmarket.com/blog/attractions/iran/ahvaz/a hvaz-attractions]

"Attractions of Ahavoz, located in the warm and pleasant center of Khuzestan region ... wants to host tourists".
آنديمشك Sālehābād instead Andimašk (Name of 41 stations of the Southern Railway);

$$
\begin{aligned}
& \text { راهآهن انديمشك جزو قديمىترين بخشهاى } \\
& \text { خطوط ريلى ايران استـ. }
\end{aligned}
$$
baxšhā-ye xotut-e reyli-ye irān ast [https://www.alibaba.ir/mag/andimeshk-attractions].

"The Andimash Railway is one of the oldest parts of the Iranian railways."

The summary examples show the unconditional use of all the suggested toponyms, the previous toponyms were not used in any documents and media.

يرندك Rahimābād instead Rيم آباد Parandak (The name of the 6th station of the Southern Railway);

محسن آباد $\quad$ Moxsenābād instead Simindāšt (The name of the 24th station of the North Railway);

نادز Nādež (The name of the 10th station of the Southern Railway);

There are many examples.

\section{MAIN PART}

It should be noted that this situation has continued since the establishment of the Uzbek Atamakom. "Another method used in the analysis of 
toponyms is seen in the fact that the words involved in noun formation are semantically similar, in their grammatical structure, i.e. in which parts of speech they participate, and finally in the word fragments that are more involved in the formation of geographical names. One-word toponyms are usually in the form of nouns and rarely adjectives. Thus, geographical names are formed in the form of certain patterns. Such patterns are called toponymic models. Each language has its own characteristics and toponymic models in the formation of toponyms. For example, Uzbek place names often consist of several elements, suffixes come after the stem, and the quality precedes the noun. In the list of toponyms of a place, this pattern is evident on many geographical maps. Hence, the toponymic model refers to the structure of toponyms" [1.28]

At the same time, it would be appropriate to distinguish the following cases on the use of toponyms in Persian and Uzbek languages:

1) place names were Persianized during the Second Academy in Persian (1968) and mainly toponyms adopted since that time are used in all documents, in the media without any changes;

2) in the Uzbek language, the change of toponymic names is still going on, and the names are allowed to be changed unreasonably. As a result, toponymic words used in previous years are used differently in documents of later years.

In general, if the toponyms given as equivalents in the Uzbek language (even if they are substantially changed) are analyzed in terms of assimilation and word formation, in some cases it is possible to see that assimilation is offered for assimilation again.

When performing their structural-semantic analysis in accordance with the principles of classification of toponymic names, there are 2 types of distinctions: a) names that appear depending on the natural characteristics of geographical objects. b) names associated with the socio-economic, political and ideological conditions, features of the development of society.

It should be noted that the name of Yashnaabad district belongs to 2 types of this classification. It is observed that the joint oykonim [ Name of the settlement] is formed on the basis of several models according to the morphological material. "Examples of joint toponyms in the form of "noun + verb" and "verb + noun" are 'Qumbosdi', 'Soykeldi', 'Khojaoldi', 'Axunqaynar', 'Toshkesar', 'Suvchiqmas', 'Qolgandaryo' [1. 46]. It is not mentioned in the Uzbek word-formation rules or in the ISO 704 standard [2. 38] that a term can be created on the basis of the model "Verb command mayli + noun". 'Yashnaabad' -' yashna' 'is the imperative mood of the verb. With this in mind, it should be noted that the term 'Yashnaabad' contradicts the rule of making the term, and the term
'Yashnaabad', which was created and proposed here, and which is currently used in all state documents, is misused.

In addition, the active speech layer of the lexicon in Persian was Persianized:

آغاز ابتدا āyāz'Beginning'; مشرق mašreq instead خاوق xā var 'The East is an example.

Here it is, شروع Šorou (arabic) and $\bar{a} y \bar{z} z$ (Persian) words also have the same value in Persian lexicon, and it is appropriate to connect it directly with the phenomenon of allomorphism in linguistics.

J. Mottaqiy and A.R. According to an article co-authored by Lutfi, allomorphism is manifested in two ways:

"To throw".

1. Allofon. انداخت [andāxt] - انداخ [andāz]

2. Allomorph. قرمز qermez "fry" [3. 36-35].

Explaining the cases of allomorphism, the researcher did not comment on whether allomorphs were formed from assimilated words. Based on the

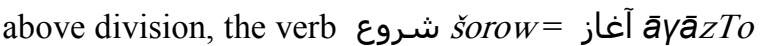
"start" provided by the Academy is allomorphic to each other. Explanatory dictionaries note that the Arabic word ابتدا ebtedā is also an allomorph (synonym) for these two words. [4] Hence, there are 2 Arabic allomorphs in a single آغاز āyāz Persian word. It is also observed that their frequency of digestion is almost the same:

آغاز طرح دوگانه سـوز كردن خودروهاى عمومى.

$\bar{A}$ yāz-e tarx-e do gāne-ye suz kardan-e xodrowhā-ye omumi [https://www.ilna.news].

"Commencement of a two-way firing project for general automobiles".

And:

يكى از بزرگ ترين مشـكلات افرادى كه

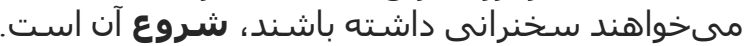

Yeki az bozorgtarin moškelāt-e afrādi ke

mixāhand soxanrāni dāšte bāšand, šoru'-ye ān ast

[https://mostafaee.com/portfolio-item/start-thelecture].

"One of the biggest problems for those who want to speak is getting it started".

The term "autonomy", "administration", 'administration', 'alternative', 'arbitrator', 'visit', 'visit', 'humanitarianism', 'privatization', 'economy', 'jarida' and 'reference book', which were already used in the Uzbek language at the beginning of its activity, , such as' plan', 'program', 'revolution', which had many Arabic origins, as well as artificial socio-political and economic terms were re-introduced. [Derivative analysis of terms is explained in more detail in Chapter 3.] For example, while the term 'revolution' was used in periodicals in the 1990s, the term 'revolution'has been used since 1993: 
"Your attitude to the word revolution was not positive [O'AS, 1993, August 5, p].

The main source in the creation or selection of the term was the possibilities of the native language [5. 14]. The reason is that any term must accurately and clearly express the meaning of a concept. This rule was not followed in the press. For example, instead of 'academy', terms such as 'baytulhikma' or 'farhangistan' are sometimes used that do not mean it. There are many such examples, such as 'administration', 'alternative', 'judge', 'institute', 'university', 'frequency', 'economy', 'newspaper', 'reference', 'plan', 'program', 'revolution' actively used.

But not all the assimilations proposed by Atamakom found their place in the language either. For example, the word 'dorulfunun', originally from the Arabic دارالفنون dār ol-fonun, was originally suggested for 'institute', 'university' assimilations, which were previously used in Uzbek. Please note that the proposed word 'dorulfunun' is also misleading. Hence, Atamaqom suggested reassimilation, and the word was even used in periodicals.

The International Standard ISO 704 states that "it is not always effective to replace words that have long been used in a language dictionary."

Since the status of the Uzbek language in

Uzbekistan, many new words have been forcibly included in the lexicon. Most of them are sociopolitical terms, which are also widely used in periodicals. But gradually it returned to the previous nomenclature, which expressed the same concept.

Here is another example:

"Diary of the Supreme Council of the Republic of Uzbekistan" [XS, 1991, January 1, p. 1].

This term "jumhuriyat"was proposed instead

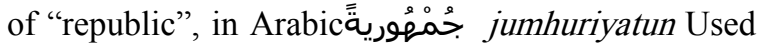
in the sense of "Republic". Hence, the Arabic word in its meaning was proposed and used in the Uzbek language. Later, one can witness that this word has gone out of the lexical structure. In particular, in all state documents, presidential decrees, laws and decrees published from 1989 to the present day, the term "republic" has been widely used in the media at the same time as the term "jumhuriyat". Probably for this reason, in recent years, only the word "republic" has been used in all documents and publications. Examples are the Law on the State Language of the Republic of Uzbekistan [6], the Constitution of the Republic of Uzbekistan, the Law on Freedom of Conscience and Religious Organizations [7], and many other normative legal acts.

Paragraph 7 of the Bulletin reads: "Whether or not this or that masculine word is replaced by another must be taken into account whether it is used in related or non-related languages. If a word in Uzbek is used in many languages of the world (related and unrelated), it is useless to try to replace it with another word. For example, the word 'republic' has a similar character" [5. 7].

We would like to note that the forcible introduction of Arabic words into the Uzbek language has increased. Here is another example:

"When we look at the pages of the inherited" Mirror "magazine ..." [XS, 1991, January 1, p. 3]

Here, 'jarida' is an adjective used for the terms 'newspaper' and 'magrazine'. In fact, jaridatun is an Arabic word that has 2 meanings in Arabic:

1) 'newspaper';

2) 'list', 'record'.

The word was adopted in Persian:

1) 'Will' means 'reference page', 'newspaper' or 'magazine' [8].

Apparently, more assimilation has been proposed to assimilation.

In addition, many words in the Uzbek model of 'Arabic basis + Persian affix / semi-affix' were introduced at the initiative of the same Atamaqom, and they are as follows:

'New Year's Address of the President of the USSR to the Soviet People" [XS, 1991, January 3, p. 2].

The 'appeal' (مراجع morāja' '\{Arabic basis $\}+$ - نامه- Persian semi-affix $\})$ is an assimilation, consisting mainly of a set of statements made by a head of state or officials to the people. Hence, the proposed word was proposed temporarily.

Another example:

"The Chairman of the Religious Board of Muslims of the Central Asian Republics and Kazakhstan, Mufti, People's Deputy of the USSR Muhammad Sadiq Muhammad Yusuf blessed the writers of newspapers with a white blessing" [XS, 1991, January 1, p. 1].

Here قلم qalam 'pen', 'is a word meaning a writing instrument, كش- -keš كشيدن ' kešidan 'The verb semi-affix from the verb to pull, to stretch. It should be noted that this word, which is formed by the Persian word-formation rule, does not exist in the Persian dictionary.

There are also a number of assimilations in the 'Arabic basis + Persian affix / semi-affix' model, most of which eventually found no place in the Uzbek lexicon. For example:

"This spirit was evident in the first minutes of the Days of Culture - in the words spoken during the meeting of guests from Tashkent on November 17 at the Nukus airport" [O'AS 1993, November 26, p. 1].

The term has been proposed for use since its earliest days 'Tayyora', 'tayyorgoh' (طيارo tayyāre

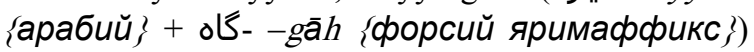




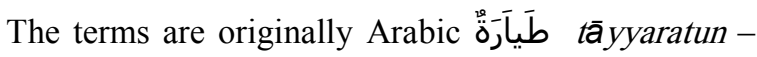
'proposed for the plane.

According to Bektemirov, "In deciding whether or not to replace a Russian word with another, it is necessary to pay attention to whether the word is used in world languages. The main way to do this is to get closer to the languages of the world, to strive for equality with them. Particular attention should be paid to such behavior in terminology. In this regard, e.g., the word republic with jumhuriyat, with the word airport tayyoragoh, not to agree to replace democracy with the word xalqchil, it would be right to leave them in place. [9.37]"

Another example:"

"Report to the Executive Committee that the Soviet Library of Uzbekistan is in a state of disrepair ..."[XS 1992, August 6, p. 3].

It is worth noting that the word "repair" is not based on the rules of word formation in Persian and Arabic, but on the basis of the rules of word formation in Uzbek. Because the word تعمير "repair" is used in Arabic to mean "construction". When the word was introduced into Uzbek, it was suggested instead of the word 'repair'. In this regard, 'repair' is an Uzbek word. Here we take two Arabic words and make a new word based on the rules of the Uzbek language.

In addition, 'school', 'class', 'teacher', 'lecture', 'balance', 'weight', 'commerce', 'region', 'heaven', 'law', 'content', which are used in everyday life in Uzbek, There are a number of Arabic words such as 'text', 'subject', 'ruler', which are used in everyday life and are deeply ingrained in the lexicon of the Uzbek language. For this reason, it is not considered appropriate to equate these words.

We would like to draw your attention to the constructions made with the Uzbek word 'oliy' and currently actively used: In Arabic, 'عَال āal is a word belonging to the family of words meaning 'high', 'old', 'high', 'first degree', 'top', and has served as the basis for the formation of many terms in Uzbek. For example, let's analyze the combination of 'Oliy Majlis':

While 'Oliy' عالى- means 'high', the word 'majlis' has a number of meanings in Arabic:
1) 'location'
2) 'meeting'
3) 'council'
4) 'Board of Directors'
5) 'tribunal', 'court'

These include a number of compound terms such as 'Supreme Court', 'High League', 'Higher Mathematics', 'Ministry of Higher Education', 'Cabinet of Ministers'.

The regulation of terms should be aimed primarily at the introduction of office work in the state language, as a number of terms in this area are waiting for their Uzbek alternative.

\section{REFERENCES}

1. Ahmadaliev Yu.I. Toponymic and geographical terminology. Fergana: 2018, - p. 26.

2. Terminology work - Principles and Methods // International Standard ISO 704. Second edition 2000-11-15. Reference number ISO 704:2000 (E). $-38 p$.

3. Mottaqiy J. va Lotfiy A.R. Allomorphy in Persian past stems. -pp. 36-35.

4.

5. Terminology of the Uzbek language. Bulletin of the Republican Terminology Committee under the Cabinet of Ministers of the Republic of Uzbekistan. Tashkent: 1992. -p. 14.

6. https://www.lex.uz/acts/121051

7. https://www.lex.uz/acts/20596

8.

9. Bektemirov H., Begmatov E. Terms of the independence period. Republican Terminology Committee under the Cabinet of Ministers of the Republic of Uzbekistan. -T .: Fan, 2002. - 37 p. 